\title{
ツベルクリン反応の促進現象に関する研究
}

第 3 報 促進現象発現時間について

\section{Studies on the Accelerated Phenomenon of Tuberculin Reaction}

\author{
Report III. Observations pursuing the Time of Manifestation \\ of the Accelerated Phenomenon \\ 横浜市立大学医学部公衆衞生学教室 (指導 宍戸昌夫助教授)
小倉 行 雄
Yukio Ogura \\ Department of Public Health, Yokohama University School of Medicine \\ (Director: Ass. Prof. M. Shishido)
}

\section{I. 緒言}

著者は第 1 報 ${ }^{47)}$ において, 前腕屈側と, 上腕内側とが ツベルクリン（以下「ツ」と略）に対してほぼ等しい反 応を呈し, 上腕内側字, 前腕屈側と同様に「ツ」反応検 査部位とするととができるととを述べ，第2 報499に执い て上腕内側を対照として, 左前腕反覆注射部位の「ツ」 促進現象を, 注射後48時間, 24 時間, 6 時間, 3 時間に 検査して, 常用部位の「ツ」反応は既に 3 時間で促進現 象军呈して掠り，6時間，24時間時の反応は，初回注射 部位の48時間時の反応掞よび常用部位の48時間時の反応 よりも強いことを報告した。

本報では「ツ」注射後の反応がごのように推移してゆ くか, 促進現象は何時間後に発現するかなごを検討した ので報告する。

\section{II. 研究方法}

\section{1）対象集団および実施時期}

昭和 32 年 10 月, 神奈川県 $Y$ 市某中学校 1 年生男子 19 名 女子17名, 計36名を対象とした。

同対象はいずれも主として左前腕屈側に，5〜10回以 上の「ッ」注射を受けているものである。B C G 接種歴 は明らかでないが，本研究奏施の年扢よびその前年に接 種を受けたものはない。

\section{2) 使用「ツ」液}

予研製標準「ツ」液を使用した。

\section{3) 注射方法および制定方法}

左前腕屈側の「ツ」検査常用部位と, 左上腕内側の初
回注射部位に, 各 $0.1 \mathrm{ml}$ ずつ, 第 1 報と同様な方法で 注意深く皮内に注射した。

注射後 15 分, 30 分, 1 時間, 2 時間, 3 時間, 6 時 間， 24 時間，48時間の 8 回にわたり第 1 報と同じ方法で 判定した。

\section{III. 研 究 成績}

1）発赤の大きさについて

i）前腕（常用部位）上上腕（初回注射部位）（括弧 内以下略) の比較

前腕 と上腕の各判定時における発赤の大きさの撒点図 を第 1 図に示す。

15分では各点は対角線上にあるが，1時間，2時間で は対角線の右側に偏り, 前腕の発赤が大きいことを示し ている。 3 時間, 6 時間も同様な傾向であるが, 24時間, 48時間では各点は対角線の両側に分布している。

ii）前腕と上腕の陽性率による比較

各判定時の前腕, 上腕をかりに現行の判定法で判定し, 発赤 $10 \mathrm{~mm}$ 以上をかりに陽性とすると, その陽性者数㧤 よび陽性率快，第 1 表に示すごとくである。

前腕の陽性率は各判定時ともに，上腕のそれより高い が，24時間，48時間および30分では各々に有意の差がな w。

iii） 発赤の平均值による前腕, 上腕の比較

各判定時の前腕, 上腕の発赤の平均值を第 2 表に示す。 前腕の平均值が, 各判定時とも上腕より大きく, 1 6 時間時では, 有意の差が認められる。 
第 1 図 (1) 前腕 (常用部位) と上睕の発赤の大きさの相関 (15分, 30分, 1 時間, 2 時間)
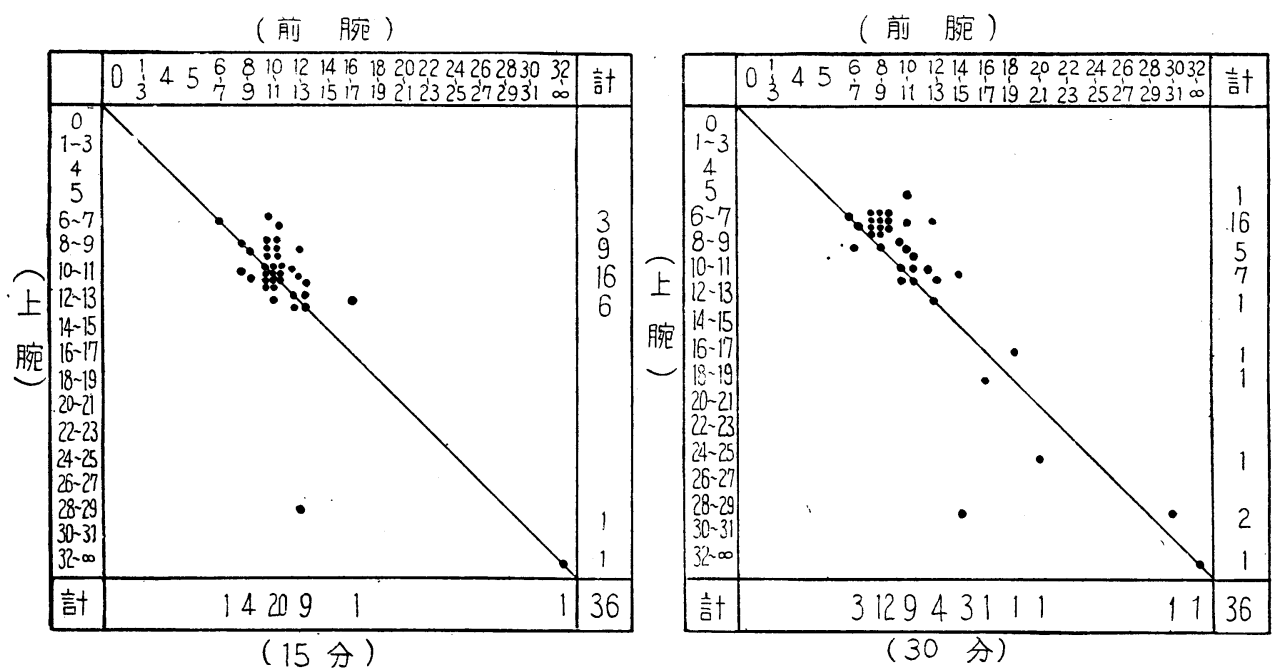

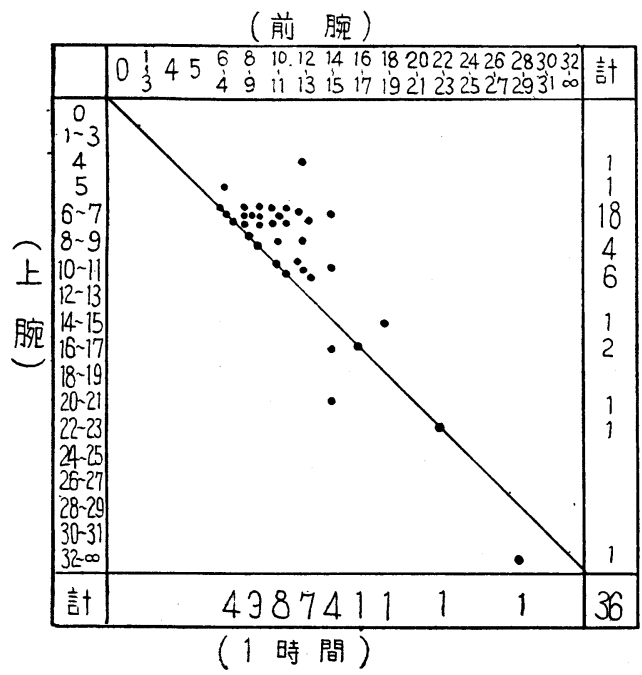

第 1 表 各制定時における陽性者および陽性率

\begin{tabular}{|c|c|c|c|c|}
\hline \multirow{2}{*}{ 判定陽性者 } & \multicolumn{2}{|c|}{ 前 } & \multicolumn{2}{|c|}{ 上 } \\
\hline & 人数 & $\%$ & 人数 & $\%$ \\
\hline 15 分 & 31 & $86.1^{*}$ & 24 & $66.7^{*}$ \\
\hline 30 分 & 21 & 58.3 & 14 & 38.9 \\
\hline 1 時間 & 23 & $63.9^{*}$ & 12 & $33.3^{*}$ \\
\hline 2 時 間 & 26 & $72.2^{*}$ & 1 & $2.8^{*}$ \\
\hline 3 時間 & 35 & $97.2^{*}$ & 6 & $16.7^{*}$ \\
\hline 6 時 間 & 36 & $100.0^{*}$ & 28 & $77.8^{*}$ \\
\hline 24 時 間 & 35 & 97.2 & 35 & 97.2 \\
\hline 48 時 間 & 35 & 97.2 & 34 & 94.4 \\
\hline
\end{tabular}

* $5 \%$ 以下の危險率で有意の差がある

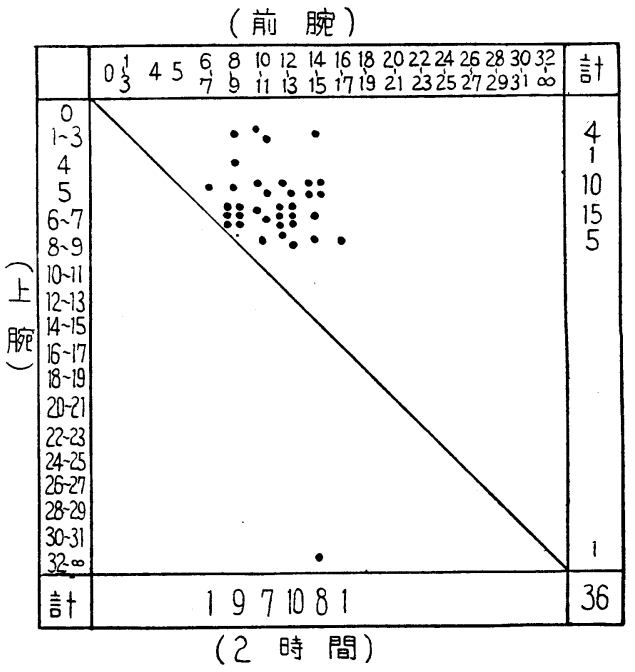

第 2 表 各制定時における発赤の大きさの 平均值 $(\mathbf{m m})$ による比較

\begin{tabular}{|c|c|c|c|}
\hline 判定時間 & 前 & 上 & $\begin{array}{l}\text { 前腕, 上腕 } \\
\text { の差 } \\
\text { (前一上) }\end{array}$ \\
\hline 15 分 & 11.5 & 11.4 & +0.1 \\
\hline 30 分 & 12.1 & 11.1 & +1.0 \\
\hline 1 時 間 & $11.6^{*}$ & $9.8^{*}$ & +1.8 \\
\hline 2 時 間 & $11.6^{*}$ & $6.6^{*}$ & +5.0 \\
\hline 3 時 間 & $16.9^{*}$ & $8.7^{*}$ & +8.2 \\
\hline 6 時間 & $21.3^{*}$ & $13.1^{*}$ & +8.2 \\
\hline 24 時 間 & 21.5 & 19.3 & +2.2 \\
\hline 48 時間 & 17.5 & 18.8 & -1.3 \\
\hline
\end{tabular}

* $5 \%$ 以下の危険率で有意の差がある 
第 1 図 (2) 前腕 (常用部位) と上腕の発赤の大きさの相関 (3 時間, 6 時間, 24 時間, 48 時間)
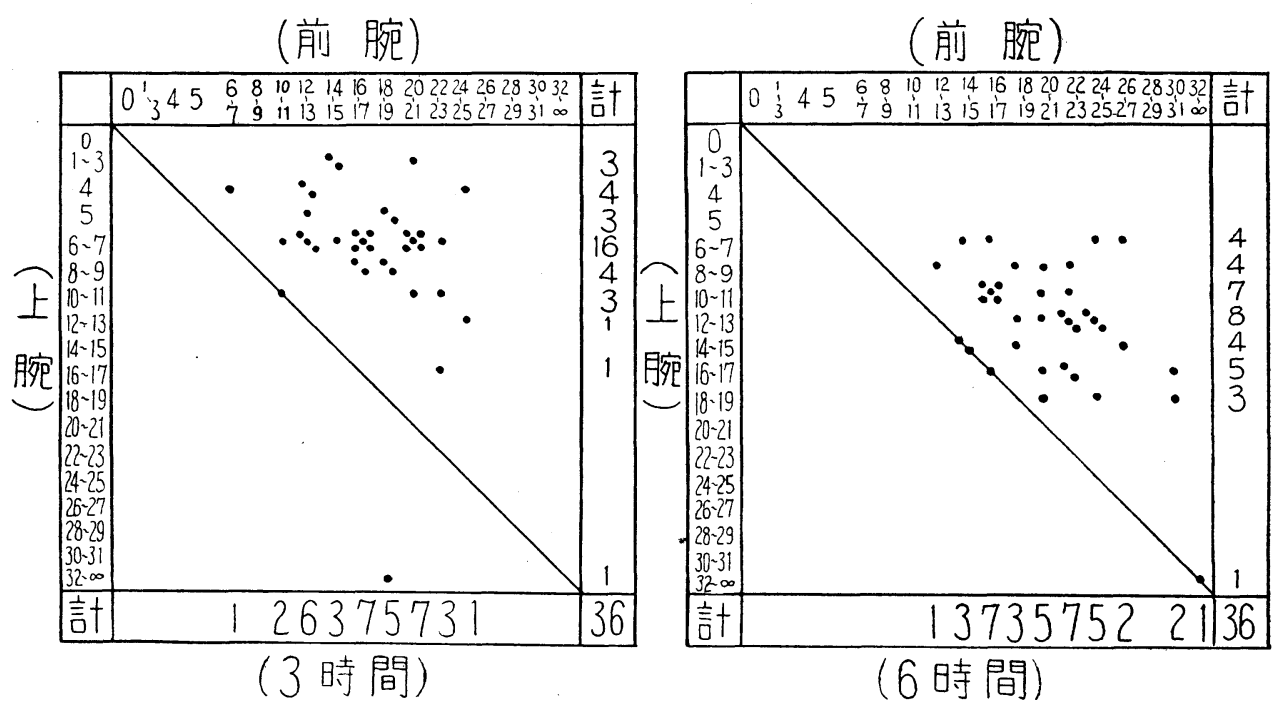

(前 腕)

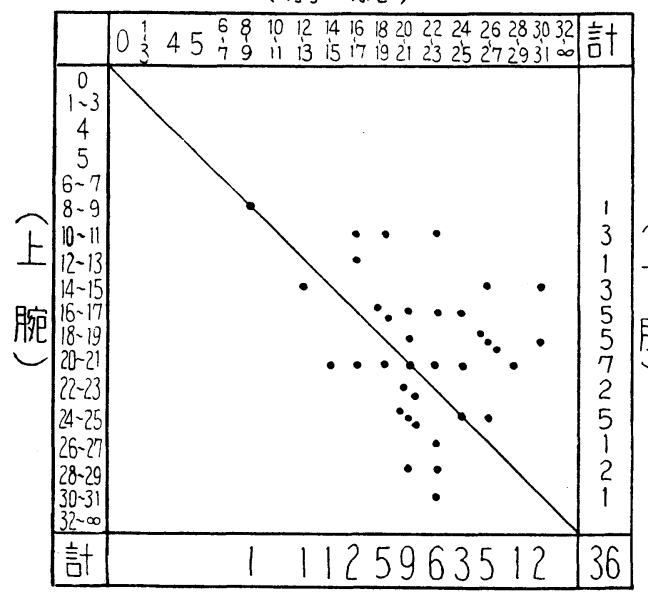

(24 時間)

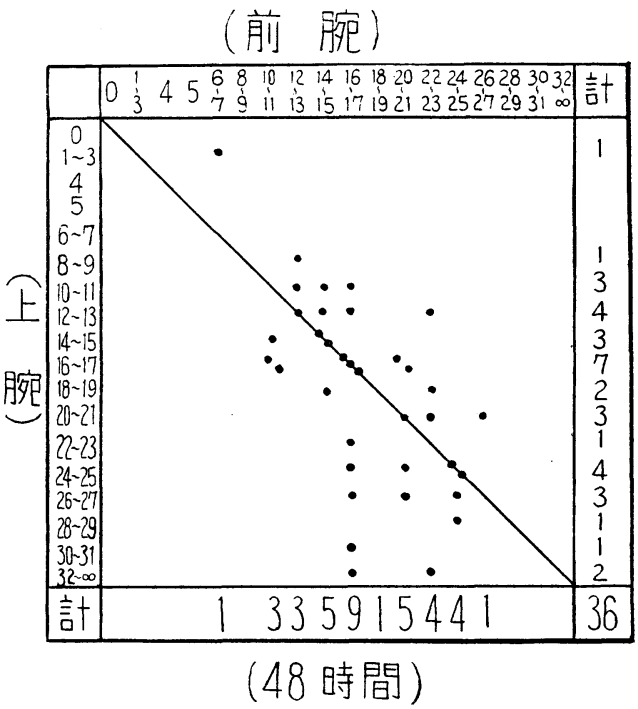

殊に 3 時間時, 6 時間時の両腕の差は著明である。 iv） 前腕, 上腕の発赤の大きさの各判定時に掞ける推

\section{移の比較}

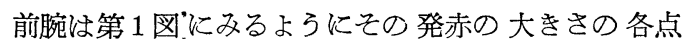
は，15分では $10 \mathrm{~mm}$ 付近に集中して分布しているが， 30 分， 1 時間とやや分散し， 2 時間ではまた集中した分布 を示している。15分，30分，1時間に異常な大きさ示 した例も， 2 時間では 6 １7 $\mathrm{mm}$ の範囲内に集つてくる。 3 時間以後は，第 2 報汇述べたょうな経過を示してい る。

上腕では 15 分では各点は $10 \mathrm{~mm}$ 付近に集つているが,

30 分, 1 時間と分布が散り, 2 時間では $6 \sim 7 \mathrm{~mm}$ 付近 に集つてくる。

3 時間より発赤は次第に大きくなつて鸟き第 2 報と同 じような経過を示すが，乙の対象では，48時間值が，24 時間の大きさょりやや小さくなつている。

平均值をみると，第 2 表抢よび第 2 図に示すような経 過を示し, 前腕では 1 時間, 2 時間で浅い谷导つくり, 3 時間， 6 時間と急激に上昇し，24時間值は僅かに 6 時間 値より大きく, 48 時間には下降し， 3 時間値と 6 時間値 の中間の大きさを示す。すなわち, 2 峯性の曲線を描く。 上腕の平均值曲線も， 2 時間で谷をつくり， 3 時間名 
ら上昇する 2 峯性の曲線となるが，乙の対象では 48 時間 值が，24時間値よりやや低くなつている。

陽性率では，前腕は30分がもつとも低く，次第に高く なつてゆき, 3 時間以後は㳘とんでが陽性を示している。

上腕は 2 時間まで下降し, 最低となり, 徐々にその陽 性率を増してゅく。

8 回の各判定時に, 最大の発赤を呈した人数ならびそ 百分率を，両腕决第 3 表に示した。

前腕，上腕とも 30 分で最大の発赤を示したものが数例 あるが, これらは反応が異常に大きく, 間もなく減少し たものであるから, 特異的なものではなく, 非特異反応 であろろ。

\section{第 3 表 各制定時において両部位において最大の ・ 発赤を示した人数ならびに陽性率}

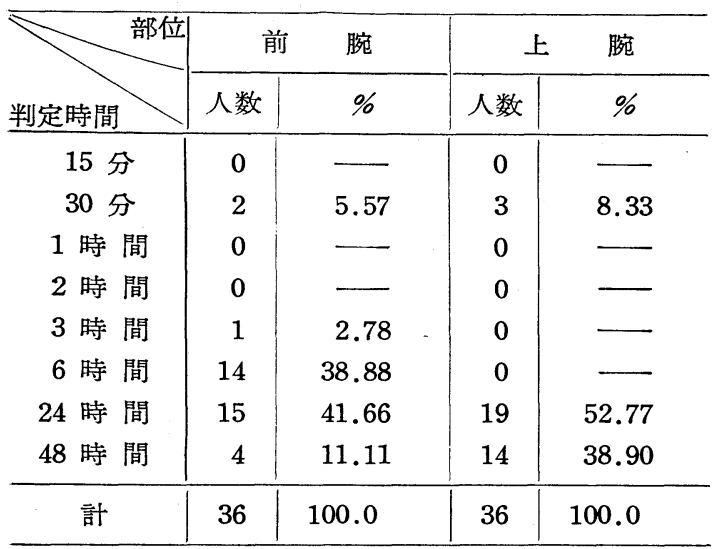

上腕では24時間で最大のものが52.8\%を占め，それ以 前に最大値を示すものはないが，前腕では， 24 時間で $41.7 \%$ ， 6 時間で $39.0 \%$ ，そして 3 時間でも $2.8 \%$ に最 大值を示して抢り，48時間以前に最大值を示すものが, 上腕に比べて多いととを示している。

\section{2）二重発赤について}

二重発赤は, 前腕 24 時間時に $22.2 \%$ 久られたのみで 48時間時にはみられなかつた。

\section{3) 硬結について}

i）前腕と上腕の比較

硬結を触知したものの数㧤よびその率は，第 4 表に示 すどとくである。

すなわち，15分では両腕とも $100 \%$ に触知でき，1 時 間までは両腕の間の触知率に有意の差がないが, 2 時間, 3 時間， 6 時間時においてい前腕に触知率が高く, 24 時 間，48時間時においては，逆に低くなり，上腕との間に いずれも有意の差が認められる。
第 2 図発赤の大きさの平均值

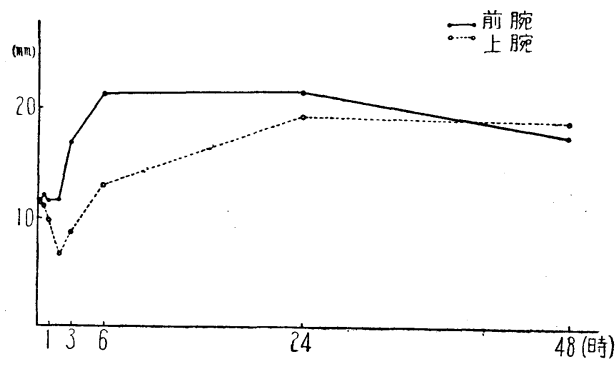

第 4 表 両部位における各判定時の硬結触 知数ならびに率

\begin{tabular}{|c|c|c|c|c|}
\hline 部位 & \multicolumn{2}{|c|}{ 前 } & \multicolumn{2}{|c|}{ 上 } \\
\hline 判定時間 & 人数 & $\%$ & 人数 & $\%$ \\
\hline 15 分 & 36 & 100.0 & 36 & 100.0 \\
\hline 30 分 & 31 & 86.1 & 32 & 88.9 \\
\hline 1 時 間 & 21 & 58.3 & 16 & 44.4 \\
\hline 2 時 間 & 29 & $80.6^{*}$ & 10 & $27.8^{*}$ \\
\hline 3 時 間 & 25 & $69.4^{*}$ & 5 & $13.9^{*}$ \\
\hline 6 時 間 & 25 & $69.4^{*}$ & 7 & $19.4^{*}$ \\
\hline 24 時 間 & 20 & $55.6^{*}$ & 30 & $83.3^{*}$ \\
\hline 48 時 間 & 1 & $2.8^{*}$ & 27 & $75.0^{*}$ \\
\hline
\end{tabular}

* $5 \%$ 以下の危険率で有意の差がある

各判定時の硬結の平均値を第 5 表に示す。 6 時間まで は前腕の硬結の平均値が，上腕より大きく，24時間， 48 時間時に扢いては逆に小さくなつている。1 時間までは 両腕の間に有意の差は認められない。

第 5 表 各制定時における硬結の大きさの平均值 (mm) による比較

\begin{tabular}{|c|c|c|c|}
\hline 判定時間 & 前 & 上 & $\begin{array}{l}\text { 前腕, 上腕の } \\
\text { 差 (前一上) }\end{array}$ \\
\hline 15 分 & 11.0 & 10.2 & +0.8 \\
\hline 30 分 & 8.8 & 8.3 & +0.5 \\
\hline 1 時 間 & 5.9 & 4.3 & +1.6 \\
\hline 2 時 間 & 8.5 & 2.3 & $+6.2^{*}$ \\
\hline 3 時 間 & 10.3 & 1.7 & $+8.6^{*}$ \\
\hline 6 時 間 & 12.4 & 3.2 & $+9.2^{*}$ \\
\hline 24 時 間 & 8.9 & 11.7 & $-2.8^{*}$ \\
\hline 48 時 間 & 0.4 & 10.8 & $-10.4^{*}$ \\
\hline
\end{tabular}

* $5 \%$ 以下の危険率で有意の差がある

ii）前腕，上腕の硬結の各判定時に抢ける推移の比較 「ッ」注射後15分では，両腕とも浮腫状の硬結を 100 
\%に触知し，その大きさは 発赤の大きさょりやや小さ い。

前腕は次第に触知率および大きさを減じてゆくが，2 時間時に既に固有の硬結を触知できるようになり， 3 時 間， 6 時間とその大きさを増し， 6 時間時に触知率，大 きさともに最大となり，24時間時には既に減少し，48時 間時では触知率は急激に減少している。

上腕では, 3 時間までは次第にその触知率, 大きさと もに減少し， 3 時間時に最低となり，固有の硬結は 6 時 間時にみられる。24時間時では急激と触知率, 大きさ己 もに増大し，48時間時にはやや減少している。

各判定時の硬結の大きさの平均値を図示すると，第 3 四のようになる。

すなわち，前腕の曲線は 1 時間を谷とし， 6 時間を頂 こする 2 峯性の曲線を描き, 上腕のそれは 3 時間を谷と
第 3 図 硬結の大きさの平均值

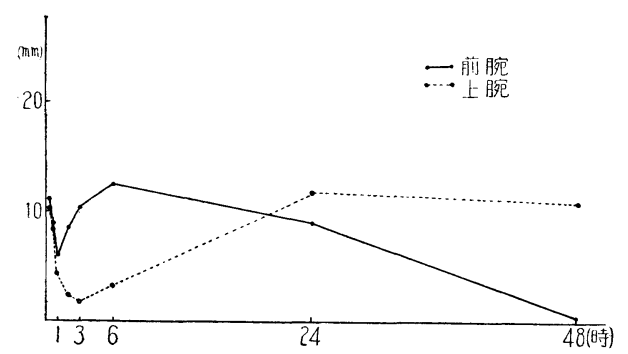

し, 次第に上昇する 2 峯性の曲線であり, 両者は 24 時間 付近で交叉している。

すなわち, 前腕では 6 時間でもつとも強い反応を現わ しているのに反して, 上腕では 48 時間で反応が最強とな つて扮り, 前者の反応の出現が, 時間的に促進して出現

第 6 表 (1) 前腕, 上腕の反応の強さの比較（その 1 )

(15 分)

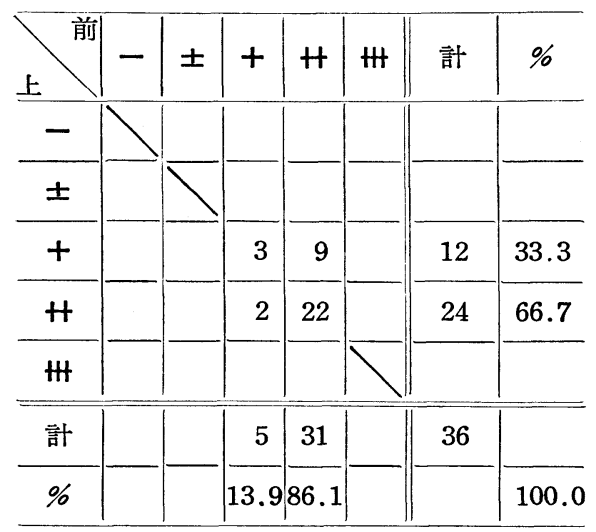

(1 時 間)

\begin{tabular}{|c|c|c|c|c|c|c|c|}
\hline 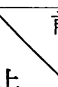 & - & \pm & + & $H$ & H & 計 & $\%$ \\
\hline- & & & & 1 & & 1 & 2.8 \\
\hline \pm & & 9 & 6 & 2 & & 17 & 47.2 \\
\hline+ & & 1 & 4 & 4 & & 9 & 25.0 \\
\hline$H$ & & & & 9 & & 9 & 25.0 \\
\hline $\mathrm{H}$ & & & & & & & \\
\hline 計 & & 10 & 10 & 16 & & 36 & \\
\hline$\%$ & & 27.8 & 27.8 & 44.4 & & & 100.0 \\
\hline
\end{tabular}

(30 分)

\begin{tabular}{|c|c|c|c|c|c|c|c|}
\hline & - & \pm & + & $H$ & HI & 計 & $\%$ \\
\hline \multicolumn{8}{|l|}{-} \\
\hline \pm & & 3 & 1 & & & 4 & 11.1 \\
\hline+ & & 1 & 11 & 6 & & 18 & 50.0 \\
\hline$H$ & & & & 14 & & 14 & 38.9 \\
\hline \multicolumn{8}{|c|}{ HI } \\
\hline 計 & & 4 & 12 & 20 & & 36 & \\
\hline$\%$ & & 11.1 & 33.3 & 55.6 & & & 100.0 \\
\hline
\end{tabular}

(2 時 間)

\begin{tabular}{|c|c|c|c|c|c|c|c|}
\hline 肖 & - & \pm & + & $H$ & $\mathrm{H}$ & 計 & $\%$ \\
\hline- & & 2 & 1 & 1 & & 4 & 11.1 \\
\hline \pm & & 1 & 7 & 15 & & 23 & 63.9 \\
\hline+ & & 1 & 2 & 5 & & 8 & 22.2 \\
\hline$H$ & & & & 1 & & 1 & 2.8 \\
\hline \multicolumn{8}{|l|}{$\mathrm{m}$} \\
\hline 計 & & 4 & 10 & 22 & & 36 & \\
\hline$\%$ & & 11.1 & 27.8 & 61.1 & & & 100.0 \\
\hline
\end{tabular}


第 6 表 (2) 前腕, 上睕の反応の強さの比較（その 2)

(3 時間)

\begin{tabular}{|c|c|c|c|c|c|c|c|}
\hline 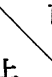 & - & \pm & + & $H$ & H & 計 & $\%$ \\
\hline - & 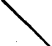 & 1 & 6 & 1 & & 8 & 22.2 \\
\hline \pm & & & 4 & 16 & & 20 & 55.6 \\
\hline+ & & & 1 & 4 & & 5 & 13.9 \\
\hline H & & & & 3 & & 3 & 8.3 \\
\hline $\mathrm{Ht}$ & & & & & & & \\
\hline 計 & & 1 & 11 & 24 & & 36 & \\
\hline$\%$ & & \multicolumn{4}{|c|}{\begin{tabular}{l|l|l|}
2.830 .566 .7 \\
\end{tabular}} & & 100.0 \\
\hline
\end{tabular}

(24 時 間)

\begin{tabular}{l|r|r|r|r|r||r|r}
\hline 前 & - & \pm & + & $H$ & $H$ & 計 & $\%$ \\
\hline 上 & $\%$ & & & & & & \\
\hline \pm & & 1 & & & & 1 & 2.8 \\
\hline+ & & & 3 & 2 & & 5 & 13.9 \\
\hline$H$ & & & 12 & 10 & 8 & 30 & 83.3 \\
\hline$H$ & & & & & & & \\
\hline \hline 計 & & 1 & 15 & 12 & 8 & 36 & \\
\hline$\%$ & & 2.8 & 41.7 & 33.3 & 22.2 & & 100.0 \\
\hline
\end{tabular}

しているととがわかる。

\section{4）反応の色調について}

反応の色調についてみると, 前腕では注射後 1 時間ま で, 上腕では 6 時間まで， U反応 (うすい色調) がみら れた。

前腕では 2 時間時より全員にH反応 (バラ赤色) を呈 するようになるが，上腕で全員がH反応を呈するように なるのは24時間時であり，前者が時間的に非常に早く 「ッ」固有の反応色調を呈するようになることが知ら れる。

前腕では，24時間時，48時間時と，漸次 $\mathrm{H}$ 反応が減じ その代りにK反応（朽葉色）が増加してくることは，第 2 報に述べたと同様である。

\section{5) 反応の強さについて}

各判定時の前腕，上腕の反応の強さを図示すれば，第 6 表捛よび第 4 図のようになる。
(6 時 間)

\begin{tabular}{l|l|l|l|l|l||r|r}
\hline 前 & - & \pm & + & $H$ & $\mathrm{H}$ & 計 & $\%$ \\
\hline 上 & $\%$ \\
\hline \pm & & & 2 & 6 & & 8 & 22.2 \\
\hline+ & & & 6 & 13 & & 19 & 52.8 \\
\hline$H$ & & & & 9 & & 9 & 25.0 \\
\hline$H$ & & & & & & & \\
\hline \hline 計 & & & 8 & 28 & & 36 & \\
\hline$\%$ & & & 22.2 & 77.8 & & & 100.0 \\
\hline
\end{tabular}

(48 時 間)

\begin{tabular}{|c|c|c|c|c|c|c|c|}
\hline 前 & - & \pm & + & $H$ & $\mathrm{HH}$ & 計 & $\%$ \\
\hline- & 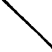 & 1 & & & & 1 & 2.8 \\
\hline \pm & & 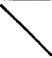 & 1 & & & 1 & 2.8 \\
\hline+ & & & 7 & & & 7 & 19.4 \\
\hline$H$ & & & 26 & 1 & & 27 & 75.0 \\
\hline $\mathrm{HH}$ & & & & & & & \\
\hline 計 & & 1 & 34 & 1 & & 36 & \\
\hline$\%$ & & 2.8 & 94.4 & 2.8 & & & 100.0 \\
\hline
\end{tabular}

すなわち，15分, 30分では, 両腕の反応の強さはほぼ等 しいが， 1 時間， 2 時間時に执いては次第に前腕の反応 が強くなり， 3 時間， 6 時間時において差はますます著 明になる。24時間時には逆にやや上腕の反応の方が強く なり，48時間時に执いては明らかに上腕の反応が強い。

すなわち, 上腕では $2 \sim 3$ 時間までは反応の強さを減 じ， 6 時間から急速に反応の強さを増してゆくが, 前腕 では 2 時間から反応の強さを増し 6 ～24時間の間に最強 となり，48時間時には急速に反応は弱まつている。

すなわち，反応の強さに抢いても，前腕の反応が，時 間的に促進しているととがわかる。

\section{IV. 考案}

「ツ」反応が，反覆注射部位に扔いて，促進現象を呈 するととは，諸家の報告するところであり，著者はこの 促進現象学時間的に考察し, 常用部位の反応は, 時間的 に著しく促進して24時間，もしくはそれ以前 6 時間頃に 

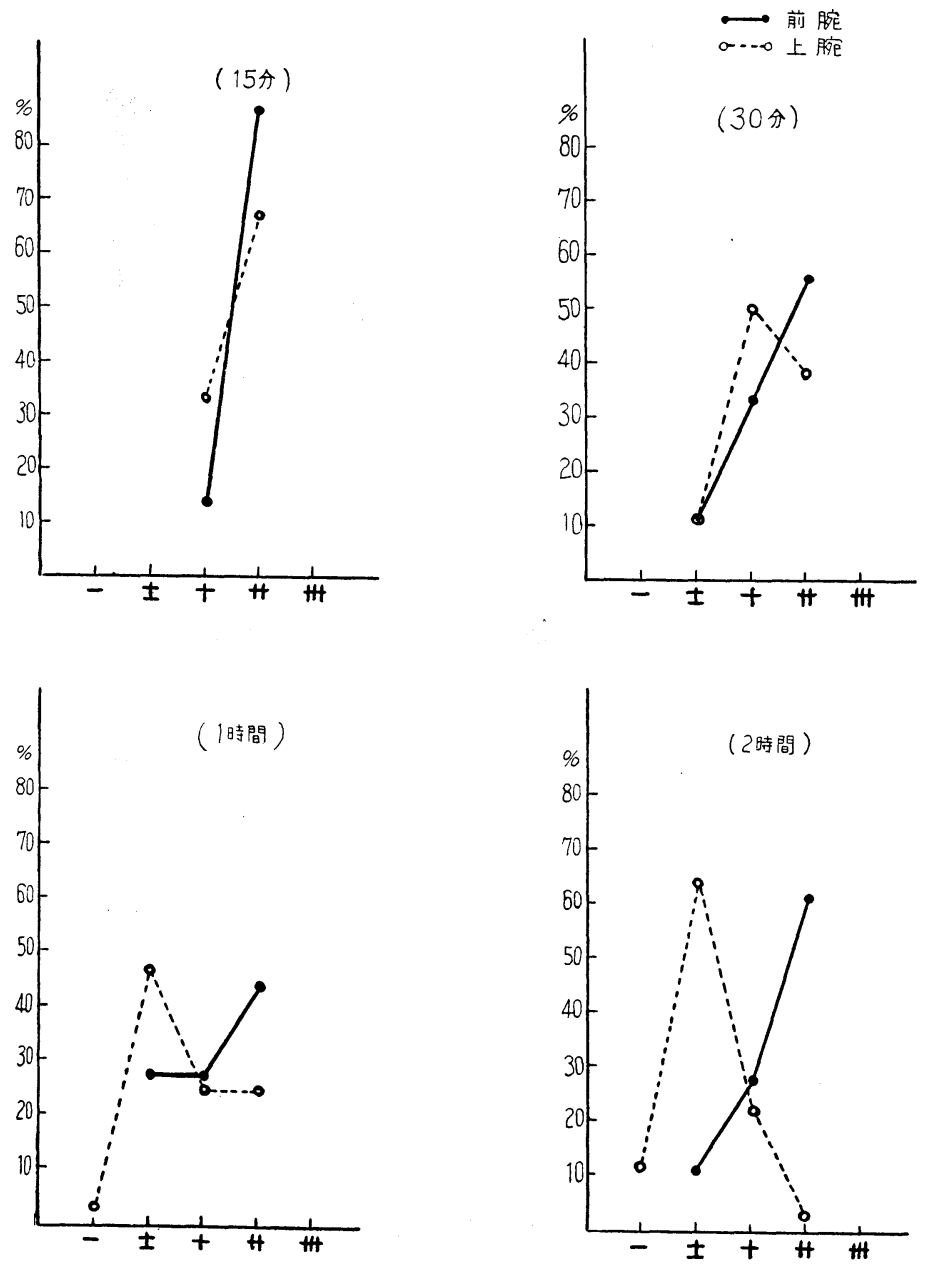

もつとも強い反応を現わし,かつ初回注射部位に比べて, 反応強度を増強することを，第 2 報に执いて述べた。

しかし，「ツ」注射後早期の反応が，いかなる変化を 現わすかについては, 僅かに松島等 ${ }^{22}$ の報告を及るの夕 で, 早期に招ける促進現象出現の様相は解明をれていな w。

著者は「ツ」反応の発赤, 硬結, 反応の色調, 反応の 強さなどについて，「ツ」注射後15分ょり観察し，早期 の反応の推移を検討した。

発赤の大きさの平均值の推移を追求した曲線を第 2 図 に示したが， 6 時間以内の成績を模式化したのが第 5 図 である。

この曲線は 双峯曲線を描いているが，これを分析し て, 第 1 峯, 第 2 峯とすると, 第 1 峯㹥注射後早期に出

現する機械的刺战や，「ツ」中に含まれる非特異物質に よる非特異反応によるものと考えられ，第 2 峯は特異反 充によるものと考えられる。この両者が合してできた双 峯曲線が,「ツ」反応曲線てあると解される。

以上の考えから, 初回注射部位の「ツ」反応の推移を 考察すると, 非特異反応は注射直後兮ら発現し， 3 時間 過ぎまで現われ，特異反応は 1 時間過ぎから発現し，両 者の曲線が 2 時間付近で交叉している。すなわち， 1 時 間過ぎから 3 時間過ぎまでは, 特異, 非特異の混じたも のが「ツ」反応曲線を形づくつていると考えられ，特異 反応は 4 時間頃から観察されると思われる。

これに対して常用部位では，非特異反応は既に 1 時間 以前から発現し，両者の混じたすのは 1 時間前から 2 時 間半位までて，以後の反応侍異反応と考えられ，反覆 


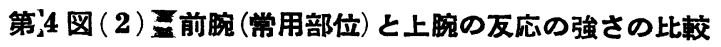
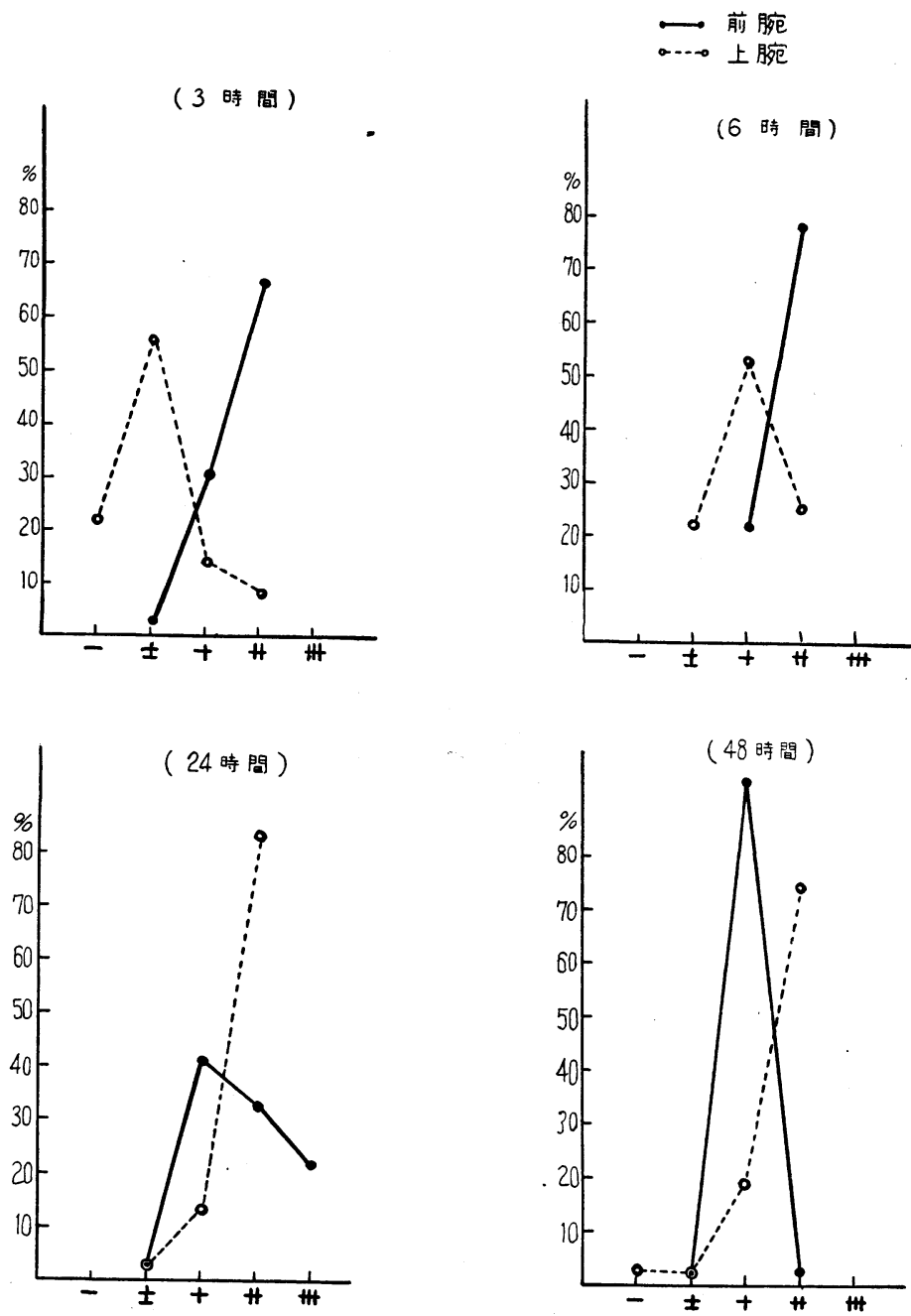

注射部位では, 初回注射部位に比べて特異反応の出現が 時間的に早まつているととがわかる。

すなわち，ての考光もつてすると，先に述べた 1 時 間以内に出現する異常に大きな発赤が, 非特異反応によ るものであること, 色調の薄いU反応が存在する時間的 な相違なども理解できる。

硬結の 平均值曲線第 3 図を模式化した 第 6 図を及る と, 発赤の場合と同様に, 双峯曲線となる。

これを発赤の場合と同様な考えで分析すると，初回注 射部位では非特異反応が注射直後から 5 時間付近まで発 現し, 特異反応は 2 時間過ぎから発現する。乙の両者の 混じたものが 2 時間過ざから 5 時間付近までの「ツ」反 応曲線を形づくつていると考えられ，特異反応は，発赤

の場合より遅れて， $5 \sim 6$ 時間から観察される。

常用部位では, 非特異反応は 2 時間以前に消失し, 特 異反応は既に30分で発現して扣り，2 時間では特異反応 が観察され，発赤の場合よりも一層促進現象が著明であ る。

第 5，6四を通じてみると，初回注射部位では，3 時 間では未だ非特異反応を混じた反応であり, 特異反応は $5 \sim 6$ 時間から観察されると考えられるが, 常用部位で は， 3 時間時には「ツ」固有の反応がみられ，しかもか なり強い反応を現わしている。

すなわち, 促進現象とは, 最強の反応が,「ツ」注射後 48時間以前に起り, 48 時間時には弱まつた反応を示すの みでなく, 固有の反応の発現が, 初回注射部位に比べて 


\section{第 5 図 発赤平均值曲線の分析}

I. 特 異 反応曲線

II. 非特異反応曲線

III.ツベルクリン反応曲線

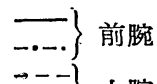

…... $\}$ 上腕

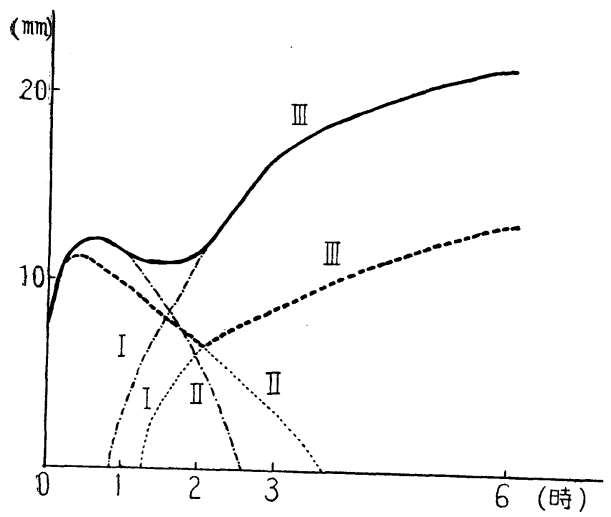

第 6 図 硬結平均值曲線の分析

I. 特異 反応曲線

II. 非特異反応曲線

III. ツベルクリン反応曲線
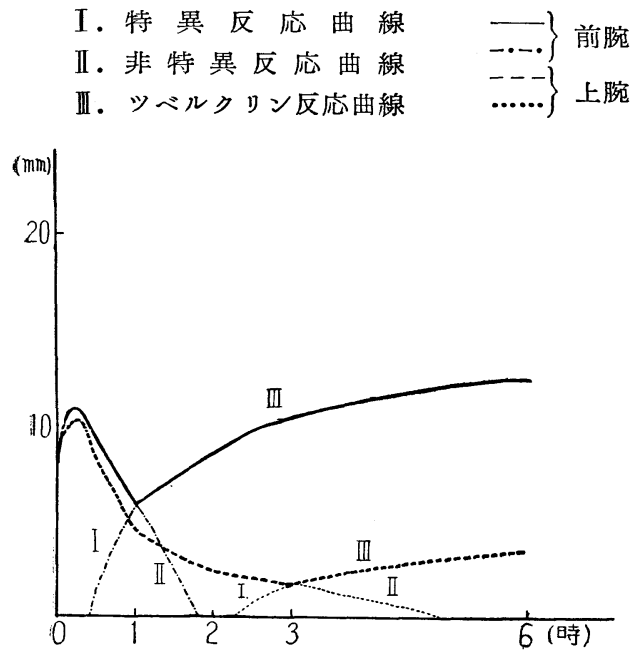

早く起り，速やかに強度が増大してゆくものであるとと がわかる。

6 時間時の反応梳，両者ともに特異反応であるが，常 用部位では非常に強い反応であり，初回注射部位では特 異反応が出現した直後の時期であることから, 両者の著 しい反応の相違も理解できる。

6 時間以後の経過妃ついては, 第 2 報に述へたと同様 である。

松島等 ${ }^{42}$ は反覆注射部位では，3〜4 時間で反応が現 われ，12時間で最強になり，初回注射部位では，12時間 頃から反応が現われると述へているが，著者は上述した ように，ょり早い時期に反応が出現し，6 時間時には両
部位ともに特異反応を呈していると考元る。

以上著者の研究は例数が少なく，B C Gの影響を考慮 しなかつたものであるが，「ッ」促進現象の発現時期, 推移等を解明しえたすのと考える。

\section{V. 結論}

中学生36名の左前腕屈側の「ツ」常用部位と, 左上腕 内側の初回注射部位に，「ツ」反応検査を行い,「ツ」 注射後 15 分， 30 分， 1 時間， 2 時間， 3 時間， 6 時間， 24 時間, 48 時間の 8 回儿判定し, 早期に扮ける「ツ」反 応の椂相, 促進現象発現の㭙期, 推移等を研究して, 次 の結果を得た。

1）初回注射部位に执いて，「ツ」はそ固有の反忘 を 2 時間前後から発現しはじめ, 時間をこもにその反応 強度定增し，48時間で最大となる。2 時間以前の反応社 非特異反応であり， 5 時間までの反応注特異反応と，非 特異反応の混じたものである。「ッ」の特異反忘は 5 〜 6 時間より観察される。

2）反覆注射部位に扢いて蛙，固有の反応は 30 分〜 1 時間で発現しはじめ, 急速にその反忘強度を増し， 6 〜 24 時間で最強となり，48時間時には減弱する。

すなわち，注射後 1 㭙間以前の反応 あり, 特異反応と, 非特異反応の混じたものは 2 時間半 位までで，3時間時には特異反応が観察される。

3）促進現象已は，最大の反応が48時間より以前飞出 現するというのみでなく，固有の反応の発現が，初回注 射部位に比べて早く発現し，かつ速やかに強度が増大し てゆくものであることが明らかにされた。

すなわち，促進現象を論ずる際には，48時間時，24時 間時の反応学検討するのみでなく，6 時間，もしくはそ れ以前の反応に注目して考察しなければならない。

本報の要旨は第28回日本衛生学会に報告する予定であ る。

終りに本研究に対し，御指導，御校閲を賜わつれ宾戸 昌夫助教授，予研結核部長柳沢謙博士，御校閲を賜わっ え萩原兼文教授に衰心より感謝の意を捧り゙る。

\section{交献}

1）室橋豊穂：結核の臨牀，2，322，1955.

2）厚生省告示 300 号 : ツベルクリン基準，1951.

3）野辺地慶三他：厚生科学, $1,16,1940$.

4）野辺地慶三他：厚生科学, $2,41,1941$.

5）柳沢 謙: 公衆衛生, 2 輯, $498,1948$.

6）柳沢 謙： BCG とッベルクリン，日本臨牀社， 
大阪, 1946.

7）小池昌四郎：結核， $23(9) ， 44 ， 1948$.

8）鈴木 寛: 結核, $23(9), 43,1948$.

9）後藤正彥: 長崎医学雑誌, $25,268,1950$.

10）益子健一：東鉄結核管理資料， 79, 1951.

11）小池昌四郎：結核予防会研究業樍, I, 77, 1951.

12）鈴木 寛：新潟医学会雑誌，65, 165, 227, 1951.

13）野辺地慶三他 : 結核, 28, 608, 1953.

14）野辺地慶三他 : 結核, 29 (増刊), 160, 1954.

15）野辺地慶三他：日本公衆衞生学雑誌, 2(増刊), $436,1955$.

16）野辺地慶三他 : 結核, 31, 51, 1956.

17）野辺地慶三他 : 結核, 31, 309, 1956.

18）野辺地慶三他 : 結核, $31,387,1956$.

19）池上宗直 : 結核，31，338，404，459，531，1956.

20）寺田幾蔵 : 結核, $31,290,333,397,1956$.

21) L. S. Arany : J. A. M. A., 152, 491, 1953.

22）前田鍵次 : 結核研究の進歩, $7,221,1954$.

23）前田鍵次 : 結核㟝療， 8, 101，1955。

24）塩田憲三他 : 結核, 30, 229, 1955.

25) WHO Tuberculosis Research Office: Bull. World Health Org., 12, 197, 1955.

26) 榎本 彰: 医学研究, $25,1645,1955$.

27）斎藤 齊：日本公衆衛生学雑誌，2(增刊), 432 , 1955.

28）柳沢 謙他：ツベルクリン反応，金原出版，東京 1955.

29) Kunt Magnus : Lancet-CCLXIX-6891, 643,
1955.

30）佐川一郎他：綜合臨牀，4，1316，1955.

31）前田鍵次他：日本公衆衞生学雑誌，3 (増刊), 367, 1956.

32）池上宗直他：日本公衆衞生学雑誌，3 (増刊), 367, 1956.

33）小倉行雄他 : 日本衛生学雑誌, $11,275,1956$.

34）野辺地慶三他 : 日本衛生学雑誌，12，77，1957.

35）斎藤 齊他：京大結核紀要， $5,230,1957$.

36) G. Heim : Brit. Klin. Tbc., 116, 417, 1957.

37）高井鐐二：ツベルクリン秘話会報告, 東京, 1957.

38）大八木重郎：ツベルクリン想話会報告, 東京, 1957.

39）小倉行雄他：日本衞生学雑誌，12，37.5, 1958.

40）ツベルクリン懇話会: 日本公衆衞生学会報告, 大 阪, 1957.

41）鳥谷虎一郎他：日本公衆衞生学会報告, 大阪, 1957.

42）松島正視他：結核，36 (増刊)，237，1957.

43) 伊東恒夫他 : 結核, $29,211,1954$.

44）渡部光雄：日本小览科学会雑誌，60，95，1956.

45) S.Gillis : Tubercle, 38, 27, 1957.

46）須永 寛他: 名古屋医学, 66, 313, 1952.

47）小倉行雄：日本塥生学雑誌，13，228，1958.

48）里見正義：日本医事新報，1756，23，1957.

49）小倉行雄：日本衙生学雑誌， $13,234,1958$. （受付： 1957 年 12 月 22 日广 